\title{
In vitro Potency of Antibiotics against Xanthomonas axonopodis pv. citri: the Causal Agent of Canker in Acid Lime
}

\author{
A. Selva Amala ${ }^{1}$, R. Akila ${ }^{1^{*}}$ S. Harish ${ }^{2}$ and R. Arunkumar ${ }^{3}$ \\ ${ }^{I}$ Department of Plant Pathology, AC \& RI, TNAU, Madurai \\ ${ }^{2}$ Centre for Plant Protection Studies, AC \& RI, TNAU, Coimbatore \\ ${ }^{3}$ Coconut Research Station, Veppankulam, India \\ *Corresponding author
}

K e y w o r d s
Acid lime,
Xanthomonas
axonopodis pv.
citri, Citrus canker,
Antibiotics

\section{A B S T R A C T}

A survey was conducted in the major acidlime growing areas of Tenkasi and Madurai districts of Tamil Nadu. The causal agent of citrus canker (Xanthomonas axonopodis pv. citri) was isolated from the plant samples collected during the survey. The isolated bacterial colonies were found to be yellow pigmented with entire margin and the cells were single rod shaped under Gram's staining. The efficacy of some antibiotics namely Streptomycin, Tetracycline, Streptomycin + Tetracycline, Cefatoxime, Cefixime, Gentamycin, Amoxillin and chloramphenicol each at the concentration of 100, 250 and $500 \mathrm{ppm}$ were evaluated against the virulent isolate of the pathogen. Among the various antibiotics, Cefatoxime $(39.07 \mathrm{~mm})$ and Cefixime $(34.18 \mathrm{~mm})$ showed maximum average inhibition zone followed by Tetracycline $(29.51 \mathrm{~mm})$.

\section{Introduction}

Acid lime (Citurs aurantifolia) is the most significant fleshy, juicy and edible fruit tree belonging to the family Rutaceae. It has now been cultivated in more than 30 countries around the world and it was thought to be originated in South East Asia (Gottwald et al., 2002). C. aurantifolia is commonly called as Lime (Nigeria), Key lime, Mexican lime,
Sour lime, Dayap, Indian lime, Egyptian lime (USDA,2013).

Citrus fruits are consumed worldwide in the form of fresh fruit or processed into citrus products and by-products. Approximately, one third of total citrus production is utilized for processing (Okwu, 2008). Ward and Kilmer, 1989 reported that acid lime is the richest source of Vitamin-C. Citrus 
cultivation is largely affected by numerous fungi, bacteria, viruses, phloem inhabiting bacteria and phytoplasma. More than 150 diseases recorded in citrus plants from nursery level to bearing stage resulting in considerable yield loss. Canker is one of the important bacterial disease caused by the bacterium Xanthomonas axonopodis pv. citri. Cankerous fruits fetch least consumer preference and market value. Canker (corky growth) is the result of excessive mitotic cell division during pathogenesis (Gabriel et al., 2000). Infection causes cankerous lesions on the leaves, stems, and fruits of citrus cultivars, including lime, oranges, and grapefruits (Lakshmi et al., 2014). Severe infection results in defoliation, die-back, deformation of fruit and premature fruit drop (Rossetti, 1977; Civerolo, 1981; Chand and Pal, 1982; Stall and Seymour, 1983)

Jadhav et al., 2018a tested four antibiotics, five bactericides and nine botanicals against the pathogen of citrus cankerunder in vitro condition. Among these, Streptocycline $(27.35 \mathrm{~mm})$ and copper oxychloride (25.53 $\mathrm{mm})$ showed maximum average inhibition zone and also Ginger (Z. officinale) was effective with the Average inhibition zone of $20.04 \mathrm{~mm}$ followed by Neem $19.87 \mathrm{~mm}$. This experiment was also designed in such a way to identify the best antibiotic against the citrus canker pathogen.

\section{Materials and Methods}

\section{Collection of diseased samples}

Survey was carried out to collect cankerous leaf samples from the acid lime orchards at 10 different places of Tenkasi and Madurai districts of Tamil Nadu, which were used for isolating the pathogen. Also, the Per cent disease index of canker disease at various places were calculated using the expression (Mc Kinney, 1923)
$\mathrm{PDI}=$

Sum of all numerical ratings $\mathrm{X} 100$

Total number of leaves graded $\mathrm{X}$ Maximum grade

\section{Processing of the collected samples}

The collected plant samples were surface sterilized using $70 \%$ ethanol. Small piece of leaf sample with typical lesions was selected and excised from the collected samples using a sterile scalpel and that piece was placed on a sterile glass slide with a drop of sterile distilled water and chopped into very small bits. The glass was kept undisturbed for 3-5 minutes.

\section{Isolation of the pathogen}

In the meantime, the bacteria (pathogen) oozed out from the infected samples to the water droplets resulted in cloudy appearance. The resulting suspension was streaked on the sterile Petri plates containing solidified Nutrient Agar (NA) medium [Peptone-5g/1, Beef extract-3g/l, Glucose-5g/l, Sodium chloride-5g/l, Agar-20g/l and Distilled water$1000 \mathrm{ml}]$ using sterile inoculation loop. These plates were incubated at $28 \pm 2{ }^{\circ} \mathrm{C}$ for $72 \mathrm{hrs}$ and observed for bacterial growth.

\section{Identification and purification of the pathogen}

Ten different isolates of the pathogen cultured on the NA medium were characterized based on the cultural (colony shape, margin, pigmentation) and morphological (cell shape) characters of the pathogen.

\section{Pathogenicity test}

In order to fulfil the Koch's postulates, pathogenicity test was carried out for the ten pathogen isolates namely Xac1 to Xac 10 following the procedure of Arshiya et al., 
2014. As a result of pathogenicity studies, the pathogenic isolate Xac1 was found to be highly virulent and this isolate was forwarded for further studies.

\section{In vitro evaluation of antibiotics}

The efficacy of antibiotics against the pathogen was evaluated by disc diffusion test (Kirby-Bauer method) (Ordax et al., 2009). About seven antibiotics each at 100, 250 and 500 ppm were tested in vitro using NA as basal medium. Twenty $\mathrm{ml}$ of two days old bacterial (virulent pathogen) broth $\left(2 \times 10^{8}\right.$ $\mathrm{cfu} / \mathrm{ml}$ ) was mixed with $100 \mathrm{ml}$ of molten sterilized NA medium and poured into Petri plates and allowed them to solidify.

The suspension of various antibiotics viz., Streptomycin, Tetracycline, Streptomycin + Tetracycline, Cefatoxime, Cefixime, Gentamycin, Amoxillin and Chloramphenicol each at 100, 250 and 500 ppm concentrations were prepared individually. Sterilized filter paper discs (Whatman No. 2) of $5 \mathrm{~mm}$ diameter were dipped into the respective solutions separately, and then placed onto the Petri plates ( $2 \mathrm{~cm}$ away from the periphery) containing solidified NA medium seeded with the test bacterium using sterile forceps. The untreated control plate was also maintained containing the solidified test bacterium seeded NA medium with a paper disc dipped in sterile distilled water. These plates were incubated at $28 \pm 1^{\circ} \mathrm{C}$ for $48 \mathrm{hrs}$ and looked for the formation of zone of inhibition around the paper disc. The results obtained were analysed statistically (Raju et al., 2012).

The antimicrobial activity of antibiotics was calculated in millimetre by the expression (Bagul and Sivakumar, 2016)

Zone of inhibition $=$ Total diameter of growth inhibited zone - diameter of paper disc

\section{Results and Discussion}

\section{Survey of canker incidence}

During the survey, it was found that the place Parankundrapuram recorded the highest incidence of the canker disease and Puliyankudi ranked second (Table 1).

\section{Identification of the pathogen}

From the observations, all the bacterial isolates were hardly distinguishable based on morphological characters but little variation was observed in pigmentation (Fig. 2). Similar results were reported by Jadhav et al., (2018) b, who got convex, yellow color bacterial colonies with entire margin.

Out of 10 isolates, only 2 isolates viz., Xac1 and Xac9 appeared bright with yellow pigmentation, all other isolates viz., Xac 2, 3, $4,5,6,8$ and 10 exhibited yellow pigmentation and the isolate Xac7 revealed dull coloration (Table 2).

All the bacterial isolates were examined for the shape of the cells under 100x magnification of compound microscope by Gram's staining technique. These cultured bacterial isolates were observed to produce single, rod shaped cells, also the cells were appeared to be pink in colour as they were gram negative bacteria (Table 2) (Fig. 3). This result correlates with the findings of Goto (1992), who have observed yellow colour colonies as a result of Xanthomonadin pigment production and rod-shaped cells while isolating citrus canker pathogen.

Potency of Antibiotics against Xanthomonas axonopodis pv. citri under in vitro condition

Antibiotics each at the concentration of 100, 250 and $500 \mathrm{ppm}$ were found to exhibit 
antibacterial activity against the virulent isolate of the pathogen compared to the untreated control (Table 3).

The average inhibition zone developed by antibiotics treatment against the pathogen ranges between $39.07 \mathrm{~mm}$ (Cefatoxime) and $20.98 \mathrm{~mm}$ (Gentamycin). Cefatoxime was observed to exhibit maximum inhibition of growth of test bacterium $(30.07 \mathrm{~mm})$ followed by Cefixime $(34.18 \mathrm{~mm})$.

Table.1 Locations of the samples collected

\begin{tabular}{|c|c|c|c|c|c|}
\hline \multirow{2}{*}{$\begin{array}{c}\text { Isolate } \\
\text { no. }\end{array}$} & \multirow[t]{2}{*}{ Place } & \multirow[t]{2}{*}{ District } & \multicolumn{2}{|c|}{ Geographical location } & \multirow{2}{*}{$\begin{array}{c}\text { Per cent } \\
\text { Disease } \\
\text { Index (PDI) } \\
\%\end{array}$} \\
\hline & & & Latitude & Longitude & \\
\hline Xac 1 & Parankundrapuram & Tenkasi & $8^{\circ} 98685^{\prime} \mathrm{N}$ & 77²4474' E & $51.11 \%$ \\
\hline Xac2 & Kaluneerkulam & Tenkasi & $8^{\circ} 9037^{\prime} \mathrm{N}$ & $77^{\circ} 4530^{\prime} \mathrm{E}$ & $42.22 \%$ \\
\hline Xac3 & Ayyanarkulam & Madurai & $9^{\circ} 9938^{\prime} \mathrm{N}$ & $77^{\circ} 8781^{\prime} \mathrm{E}$ & $33.33 \%$ \\
\hline Xac4 & Kadayanallur & Tenkasi & $9^{\circ} 0779^{\prime} \mathrm{N}$ & $77^{\circ} 3452^{\prime} \mathrm{E}$ & $35.56 \%$ \\
\hline Xac5 & Puliyankudi & Tenkasi & $9^{\circ} 1725^{\prime} \mathrm{N}$ & $77^{\circ} 3956^{\prime} \mathrm{E}$ & $46.67 \%$ \\
\hline Xac6 & Checkanurani & Madurai & $9^{\circ} 9420^{\prime} \mathrm{N}$ & $77^{\circ} 9724^{\prime} \mathrm{E}$ & $28.89 \%$ \\
\hline Xac7 & Kuruvikulam & Tenkasi & $9^{\circ} 1780^{\prime} \mathrm{N}$ & $77^{\circ} 6694^{\prime} \mathrm{E}$ & $31.11 \%$ \\
\hline Xac8 & Kadayalurutti & Tenkasi & $9^{\circ} 0268^{\prime} \mathrm{N}$ & $77^{\circ} 4336^{\prime} \mathrm{E}$ & $26.67 \%$ \\
\hline Xac9 & $\mathrm{AC} \& \mathrm{RI}$ & Madurai & $9^{\circ} 9699^{\prime} \mathrm{N}$ & $78^{\circ} 2040^{\prime} \mathrm{E}$ & $35.56 \%$ \\
\hline Xac10 & Kalluthu & Madurai & $10^{\circ} 0603^{\prime} \mathrm{N}$ & $77^{\circ} 8226^{\prime} \mathrm{E}$ & $44.44 \%$ \\
\hline
\end{tabular}

Table.2 Cultural and morphological features of the isolates

\begin{tabular}{|l|c|c|c|c|c|}
\hline \multirow{2}{*}{ Isolates } & \multicolumn{4}{|c|}{ Cultural characters } & $\begin{array}{c}\text { Morphological } \\
\text { characters }\end{array}$ \\
\cline { 2 - 6 } & $\begin{array}{c}\text { Colony } \\
\text { shape }\end{array}$ & Pigmentation & $\begin{array}{c}\text { Colony } \\
\text { margin }\end{array}$ & $\begin{array}{c}\text { Colony } \\
\text { elevation }\end{array}$ & Cell shape \\
\hline Xac 1 & Circular & Bright yellow & Entire & Convex & Single rod \\
\hline Xac2 & Circular & Yellow & Entire & Convex & Single rod \\
\hline Xac3 & Circular & Yellow & Entire & Raised & Single rod \\
\hline Xac4 & Circular & Yellow & Entire & Convex & Single rod \\
\hline Xac5 & Irregular & Yellow & Curled & Raised & Single rod \\
\hline Xac6 & Circular & Yellow & Entire & Convex & Single rod \\
\hline Xac7 & Circular & Straw yellow & Entire & Convex & Single rod \\
\hline Xac8 & Circular & Yellow & Entire & Raised & Single rod \\
\hline Xac9 & Circular & Bright yellow & Entire & Convex & Single rod \\
\hline Xac10 & Circular & Yellow & Entire & Convex & Single rod \\
\hline
\end{tabular}


Table.3 Out-turn of in vitro treatment of Antibiotics against Xanthomonas axonopodis pv. citri

\begin{tabular}{|c|c|c|c|c|c|}
\hline \multirow{2}{*}{$\begin{array}{l}\text { Tr. } \\
\text { No. }\end{array}$} & \multirow[t]{2}{*}{ Treatment } & \multicolumn{3}{|c|}{ Mean Zone of Inhibition* (mm) at } & \multirow{2}{*}{$\begin{array}{c}\text { Average } \\
\text { inhibition } \\
(\mathbf{m m})\end{array}$} \\
\hline & & 100 ppm & $250 \mathrm{ppm}$ & 500 ppm & \\
\hline $\mathbf{T 1}$ & Streptomycine & $\begin{array}{l}26.90 \\
(\mathbf{5 . 2 3})\end{array}$ & $\begin{array}{l}26.75 \\
\mathbf{( 5 . 2 2 )}\end{array}$ & $\begin{array}{c}27.5 \\
(\mathbf{5 . 2 9})\end{array}$ & $\begin{array}{l}27.05^{d} \\
(\mathbf{5 . 2 5})\end{array}$ \\
\hline $\mathbf{T} 2$ & Tetracycline & $\begin{array}{l}28.80 \\
\mathbf{5 . 4 1 )}\end{array}$ & $\begin{array}{c}28.8 \\
(\mathbf{5 . 4 1 )}\end{array}$ & $\begin{array}{l}30.95 \\
(\mathbf{5 . 6 1 )}\end{array}$ & $\begin{array}{l}29.52^{c} \\
(5.48)\end{array}$ \\
\hline T3 & Streptomycin + Tetracycline & $\begin{array}{l}20.35 \\
\mathbf{( 4 . 5 7 )}\end{array}$ & $\begin{array}{c}21 \\
(\mathbf{4 . 6 3})\end{array}$ & $\begin{array}{c}25 \\
(\mathbf{5 . 0 5})\end{array}$ & $\begin{array}{l}22.12^{\mathrm{e}} \\
(\mathbf{4 . 7 5})\end{array}$ \\
\hline T4 & Cefixime & $\begin{array}{l}31.55 \\
(\mathbf{5 . 6 6 )}\end{array}$ & $\begin{array}{l}33.95 \\
\mathbf{( 5 . 8 7 )}\end{array}$ & $\begin{array}{l}37.05 \\
(\mathbf{6 . 1 3})\end{array}$ & $\begin{array}{c}34.18^{\mathbf{b}} \\
(\mathbf{5 . 8 9})\end{array}$ \\
\hline T5 & Cefatoxime & $\begin{array}{l}36.00 \\
(\mathbf{6 . 0 4})\end{array}$ & $\begin{array}{l}37.65 \\
(\mathbf{6 . 1 8})\end{array}$ & $\begin{array}{l}43.55 \\
(\mathbf{6 . 6 4 )}\end{array}$ & $\begin{array}{l}39.07^{\mathrm{a}} \\
(\mathbf{6 . 2 9})\end{array}$ \\
\hline T6 & Gentamycin & $\begin{array}{l}18.35 \\
\mathbf{( 4 . 3 4 )}\end{array}$ & $\begin{array}{l}21.45 \\
\mathbf{( 4 . 6 9 )}\end{array}$ & $\begin{array}{l}23.15 \\
\mathbf{( 4 . 8 6 )}\end{array}$ & $\begin{array}{l}20.98^{f} \\
(4.63)\end{array}$ \\
\hline $\mathbf{T 7}$ & Amoxillin & $\begin{array}{l}23.10 \\
\mathbf{( 4 . 8 5 )}\end{array}$ & $\begin{array}{l}27.55 \\
\mathbf{( 5 . 2 9 )}\end{array}$ & $\begin{array}{l}28.95 \\
\mathbf{( 5 . 4 3 )}\end{array}$ & $\begin{array}{l}26.53^{d} \\
(\mathbf{5 . 1 9})\end{array}$ \\
\hline T8 & Chloramphenicol & $\begin{array}{l}19.95 \\
\mathbf{( 4 . 5 2 )}\end{array}$ & $\begin{array}{l}22.45 \\
\mathbf{( 4 . 7 9 )}\end{array}$ & $\begin{array}{l}23.75 \\
(\mathbf{4 . 9 2 )}\end{array}$ & $\begin{array}{l}22.05^{\mathrm{e}} \\
\mathbf{( 4 . 7 5 )}\end{array}$ \\
\hline \multirow[t]{2}{*}{ T9 } & Control & $\begin{array}{c}0.00 \\
(\mathbf{0 . 7 1})\end{array}$ & $\begin{array}{c}0.00 \\
(\mathbf{0 . 7 1})\end{array}$ & $\begin{array}{c}0.00 \\
(\mathbf{0 . 7 1})\end{array}$ & $\begin{array}{l}0.00^{\mathrm{g}} \\
(\mathbf{0 . 7 1})\end{array}$ \\
\hline & $\mathrm{CD}(\mathrm{P}=\mathbf{0 . 0 1})$ & \multicolumn{4}{|c|}{1.305} \\
\hline
\end{tabular}

*Mean of three replications

[Figures in parenthesis are square root transformed values]
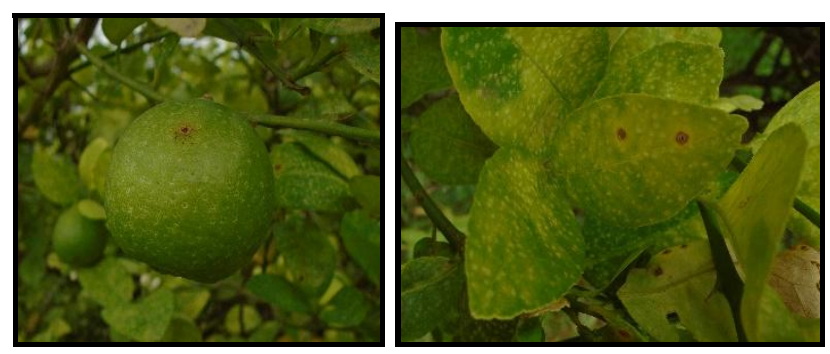

Fig.1 Cankerous growth on fruit and leaf of acid lime

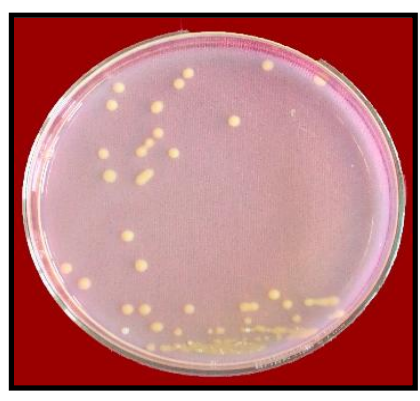

Fig.2 Isolate Xac1

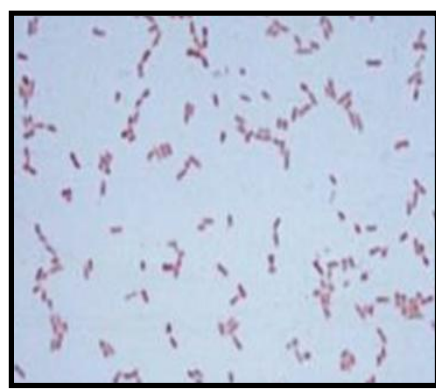

Fig.3 Gram staining 


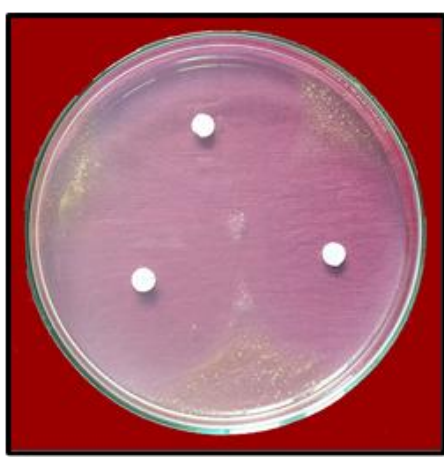

Cefatoxime

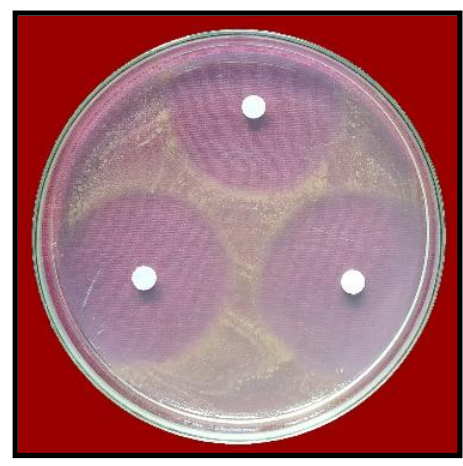

Cefixime

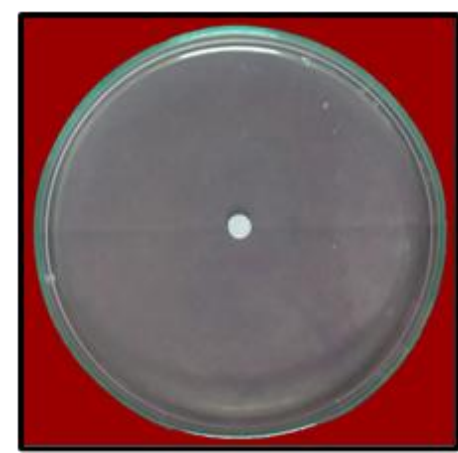

Control

Fig.4 In vitro efficacy of antibiotics against Xanthomonas axonopodis pv. citri

Ali et al., 2017, evaluated antibacterial activity of some antibiotics against the citrus canker pathogen. Highest antibiotic activity was exhibited by Gentamycin $(10 \mu \mathrm{g} /$ disc $)$ with $21 \mathrm{~mm}$ diameter of inhibition zone followed by both Chloramphenicol and Tetracycline $(30 \mu \mathrm{g} / \mathrm{disc})$ showing the same inhibition zone $(20.6 \mathrm{~mm})$.

Mubeen et al., (2015) also assessed the sensitivity of various antibiotics by disc diffusion method against Xanthomonas axonopodis pv. citri. They recorded that inhibition zone of $1.8 \mathrm{~cm}$ and $2.2 \mathrm{~cm}$ were produced by Streptomycin sulphate and Kanamycin sulphate respectively, while Ampicillin and Chloramphenicol did not show any inhibition zone against the pathogen.

\section{References}

Ali, M. R. Hasan, M. F. Lia, R. S. Akter, A. Sumi, M. S. E. Hossain, M. F. Hasan, S.M.Z. Islam, M. A. Khalekuzzaman, M. and Sikdar, B. 2017. Isolation and characterization of a canker disease causing pathogen from Citrus aurantifolia and evaluation of its biological control measure. J. Entomol. Zool. Stud. 5(6): 1526-1532

Arshiya, M. Suryawanshi, A. More, D. and
Baig, M. M. V. 2014. Repetitive PCR based detection of Genetic Diversity in Xanthomonas axonopodis pv citri Strains. J. Appl. Biol. Biotechnol. 2(1): 17-22

Bagul, S. U. and Sivakumar, M.S. 2016. Antibiotic susceptibility testing: A review on Current practices. Int. J. Pharm. 6(3): 11-17.

Chand, J. N. and Pal, V. 1982. Citrus canker in India and its management. In: Problems of citrus diseases in India. S.P. Raychaudhuri and Y.S. Ahlawat, Eds. Surabhi Printers and Publishers, New Delhi. Pp. 21-26.

Civerolo, E. L. 1981. Citrus bacterial canker disease: An overview. Proc. Intn. Soc. Citric. 1: 390-394.

Gabriel, D.W. Duane, Y.P. and Ramadugu, C. 2000. The molecular mechanism of citrus canker pathogenicity and a gene engineering approach to control. Int. Soc. Citriculture Cong. 51

Gotto, M. 1992. Citrus canker. In. Kumar,J. Chaube, H.S. Singh, U.S. Mukhopadhyay, A.N. (Eds). Plant Diseases of International Importance (Vol III) Diseases of Fruit Crops. New Jersy. Prentice Hall. Inc. 107-208

Gottwald, T. R. Graham, J. H. Schubert, T. S. 2002. Citrus canker: the pathogen and its impact. Plant Health Prog. 10:32. 
Jadhav, R. R. More, A. S. Apet, K. T. and Dandnaik, B. P. 2018a. In-vitro bioefficacy of different antibiotics, bactericides and botanicals against (Xanthomonas axonopodis pv. Citri.) causing bacterial canker of Kagzi Lime. Int.J.Curr.Microbiol.App.Sci. Special Issue-6: 1693-1699

Jadhav, R. R. More, A. S. Apet, K. T. and Dandnaik, B. P. 2018b. Cultural and Bio-Chemical Characterization of Xanthomonas axonopodis pv. citri: Causing Citrus Canker. Int.J.Curr.Microbiol.App.Sci. Special Issue-6: 1682-1687

Lakshmi, T. N. Gopi, V. Gouri Sankar, T. Sarada, G. Lakshmi, L. M. and Ramana, K.T.V. 2014. Status of diseases in sweet orange and acid lime orchards in Andhra Pradesh, India. Int. J. Curr. Microbiol. App. Sci. 3(5):513518.

Mc Kinney. 1923. Influence of Soil temperature and moisture on the influence of wheat seedlings by Helminthosporium sativa. J. agric. Res. 26:196-217.

Mubeen, M. Arshad, H. M. Iftikhar, Y. Bilqees, I. and Arooj, S. 2015. In-vitro efficacy of antibiotics against Xanthomonas axonopodis pv. citri through inhabitation zone techniques. Int. J. Agric. App. Sci. 7(1): 67-71.

Okwu, D. E. 2008. Citrus fruits: a rich source of phytochemicals and their roles in human health: a review. Int. J. Chem. Sci. 6(2):451-471.

Ordax, M. Biosca, E. Wimalajeewa, S. Lopez, M. and Marco-Noales, E. 2009. Survival of Erwinia amylovora in mature apple fruit calyces through the viable but nonculturable (VBNC) state. J. App. Microbiol. 107(1):106-116

Raju, J. Benagi, B. Jaylakshmi, V. I. Angadi, K. Basha, S. G and Sonavane, P. S. 2012. In vitro evaluation of chemicals, botanicals and bioagents against the bacterial blight of pomegranate caused by Xanthomonas axonopodis pv. punicae. Internat. J. P1. Protec. 5(2) 315-318.

Rossetti, V. 1977. Citrus canker in Latin America: A review. Proc. Int. Soc. Citric., 3: 918-924

Stall, R. E. and Seymour, C. P. 1983. Canker, a threat to citrus in the Gulf- Coast States. Plant Dis., 67: 581-585.

USDA. 2013. Agricultural Research Service, United States Department of Agriculture. National Nutrient Database for Standard Reference, Release 26 Software v.1.3.1. Retrieved December. 13.

Ward, R. W. and Kilmer, R. L. 1989. The citrus industry: a domestic and international economic perspective. Iowa State University Press.

\section{How to cite this article:}

Selva Amala, A., R. Akila, S. Harish and Arunkumar, R. 2020. In vitro Potency of Antibiotics against Xanthomonas axonopodis pv. citri: the Causal Agent of Canker in Acid Lime. Int.J.Curr.Microbiol.App.Sci. 9(12): 2103-2109. doi: https://doi.org/10.20546/ijcmas.2020.912.247 